\title{
The effect of shift work on the diet of accident and emergency nurses at the main general hospital in Malta
}

\author{
J. Seychell ${ }^{1}$ and S. Reeves ${ }^{2}$ \\ ${ }^{1}$ Clinical Nutrition Unit, Mater Dei Hospital, Msida, Malta and ${ }^{2}$ Health Science Research Centre, University of \\ Roehampton, London, SW15 4JD
}

In Malta $22.2 \%$ of workers are engaged in shift work ${ }^{(1)}$. Shift work can result in altered physical activity, eating and sleeping patterns that may disrupt the natural circadian rhythm and in the long term be detrimental to health ${ }^{(2)}$. This study aims to investigate the effect of shift work on dietary intake among nurses working in the Accident and Emergency Department of the main general hospital in Malta.

The study was cross-sectional and included a questionnaire to investigate shift work, life style, anthropometric measurements and a food frequency questionnaire (FFQ); the EPIC-Norfolk FFQ adapted to reflect the Maltese diet. Ethical approval was obtained from the University of Roehampton, the University of Malta and the Mater Dei Hospital Authority. 123 nurses were recruited and 110 completed the study. The participants were divided into 3 groups on the basis of their usual work rota: day nurses $(\mathrm{n}=29,31 \%$ male and $69 \%$ female), rotating shift nurses $(n=68,28 \%$ male and $72 \%$ female) and night shift nurses $(n=13,23 \%$ male and $77 \%$ female).

\begin{tabular}{|c|c|c|c|c|c|c|}
\hline & \multicolumn{2}{|c|}{ Day Nurses } & \multicolumn{2}{|c|}{ Rotating Shift Nurses } & \multicolumn{2}{|c|}{ Night Shift Nurses } \\
\hline & Mean & SD & Mean & SD & Mean & SD \\
\hline BMI $\left(\mathrm{kg} / \mathrm{m}^{2}\right)$ & 25.6 & $5 \cdot 2$ & $26 \cdot 4$ & $5 \cdot 0$ & $27 \cdot 0$ & $3 \cdot 1$ \\
\hline Waist circumference $(\mathrm{cm})$ & $82 \cdot 4$ & $12 \cdot 5$ & 85.4 & $14 \cdot 3$ & 91.6 & 11.8 \\
\hline Energy (kcal) & 1722 & 486 & $2065^{*}$ & 655 & 1963 & 506 \\
\hline Carbohydrate (g) & $186 \cdot 4$ & $56 \cdot 9$ & 221.8 & $70 \cdot 4$ & $210 \cdot 4$ & 64.9 \\
\hline Fat $(\mathrm{g})$ & $66 \cdot 2$ & $21 \cdot 7$ & $82 \cdot 2^{*}$ & $32 \cdot 2$ & $77 \cdot 1$ & $26 \cdot 7$ \\
\hline Protein (g) & 95.4 & 29.9 & $113 \cdot 3$ & $24 \cdot 1$ & $114 \cdot 6^{*}$ & 17.9 \\
\hline Alcohol (g) & $6 \cdot 4$ & 8.8 & $5 \cdot 6$ & $5 \cdot 3$ & $2 \cdot 8$ & $3 \cdot 3$ \\
\hline Fibre $(\mathrm{g})$ & $19 \cdot 4$ & $8 \cdot 2$ & $24 \cdot 3$ & $10 \cdot 2$ & $29 \cdot 3^{*}$ & 9.0 \\
\hline
\end{tabular}

${ }^{*} \mathrm{P} \leqslant 0.05$

Shift working nurses had significantly higher intakes of total energy $(p=0 \cdot 04)$, protein $(p=0 \cdot 04)$, fat $(p=0 \cdot 05)$ and fibre $(p=0 \cdot 007)$ compared to day nurses. However day nurses were more likely to smoke $(p=0.009) .40 \%$ of nurses had fat intakes higher than the recommendations. There were no significant differences in exercise frequency nor anthropometric measurements between groups. Recruiting a larger number of night shift workers would strengthen the results. Overall the findings in Malta were similar to that of shift workers in other studies ${ }^{(3,4)}$. Recommendations for shift working nurses should ensure healthy meals are available and adequate levels of sleep and exercise are maintained.

This work was supported by a scholarship scheme through the Operational Programme II - cohesion policy, co-financed by the European Social Fund and the Government of Malta.

1. Formosa M (2009) Working time in the European Union: Malta. http://www.eurofound.europa.eu/observatories/eurwork/comparativeinformation/national-contributions/malta/working-time-in-the-european-union-malta.

2. Smith MR \& Eastman CI (2012) Nat Sci Sleep 4, 111-132.

3. Morikawa Y et al. (2008) J Occup Health 50,270-278.

4. Pasqua IC \& Moreno CRC (2004) Chronobiol Int 21, 949-960. 